International Journal of Economics, Business and Accounting Research (IJEBAR)

Peer Reviewed - International Journal

Vol-4, Issue-1, 2020 (IJEBAR)

E-ISSN: 2614-1280 P-ISSN 2622-4771

https://jurnal.stie-aas.ac.id/index.php/IJEBAR

\title{
ANALYSIS TRIPLE BOTTOM LINE AND FACTORS THAT INFLUENCE: DISCLOSURES IN SHARIA COMPANIES IN INDONESIA COUNTRIES
}

\author{
Agus Salihin \\ Students of the Sharia Economics Masters Program \\ Sunan Kalijaga State Islamic University Yogyakarya \\ Email:agussalihin03@gmail.com
}

\begin{abstract}
Triple battom line is a corporate report disclosure concept. One of the instruments used in company report disclosures involves corporate social environmental responsibility. Then the purpose of this study is to reveal corporate social responsibility such as Company Size, Profitability, Leverage, Share Ownership, and Liquidity that can influence the Triple Battom Line disclosure in sharia companies listed in the Jakarta Islamic Index (JII) for the 2015-2018 period. This type of research is quantitative research. Sampling using a proposive sampling method with sampling based on certain criteria, to obtain samples in this study were 10 companies registered in the Jakarta Islamic Index (JII) from 2015-2018. The data used is secondary data from the company's annual financial statement data from 2015-2018. The data analysis technique uses multiple linear regression. As for the results of the study, it shows that partially company size, profitability and leverage variables affect the disclosure of Triple Battom Line on companies listed in JII for the period of 2015-2018. While the share ownership and liquidity variables do not affect the disclosure of Triple Battom Line for companies listed in JII for the period of 2015-2018. The simultaneous variables of company size, liquidity, leverage, share ownership and liquidity affect the Triple Battom Line disclosure in companies listed on JII for the period 2015-2018. For the results of the test of the coefficient of determination ( $\mathrm{R}$ square) variable company size, profitability, leverage, share ownership and liquidity can affect the Triple Battom Line disclosure in companies listed on the Jakarta Islamic Index (JII) for the 20152018 period of $86.3 \%$.
\end{abstract}

Keywords: Triple Battom Line, Company Size, Profitability, Leverage, Share Ownership, Liquidity.

\section{Introduction}

Triple Bottom Line has a concept in building corporate profits. The profits to be gained by companies are part of profits, while People are defined as social responsibility. Whereas Planet is a responsibility for the environment. So that the achievement of sustainable development cannot be separated from the fulfillment of social and environmental responsibilities (Aulia and Kartawijaya, 2011). Many companies have voluntarily implemented their social responsibilities, including the Indonesian State. Disclosure of corporate social responsibility is designed with items that focus on the concept of social responsibility. This was conveyed by Elkington (1997) who argues that, if a company can grow sustainably then its evaluation system is not seen from only one aspect but other aspects such as social responsibility. 
International Journal of Economics, Business and Accounting Research (IJEBAR)

Peer Reviewed - International Journal

Vol-4, Issue-1, 2020 (IJEBAR)

E-ISSN: 2614-1280 P-ISSN 2622-4771

https://jurnal.stie-aas.ac.id/index.php/IJEBAR

Fulfillment of environmental social responsibility will have an impact on achieving easier sustainable development. TBL is used as a way to express social, economic and environmental responsibility in each company. TBL is defined as a work method for measuring and reporting company performance against economic, social and environmental parameters. In addition TBL is also used to capture the entire set of values, problems, and processes that companies must overcome to minimize losses resulting from their activities and to create economic, social and environmental value.

Seeing company performance using only economic measures is not considered adequate. Thus, it is emphasized in TBL that company performance must be measured not only on economic criteria but also social and environmental. In addition, while traditional financial reports mainly focus on profitability and other financial performance, TBL's economic dimension is intended to capture and present a comprehensive view of the company's economic interactions with all stakeholders including shareholders, customers, employees, government, the public, and the general public.

The importance of measuring corporate social responsibility makes researchers interested in conducting research on variables that influence the disclosure of corporate social responsibility, namely company characteristics including variables of company size, profitability, leverage, stock ownership and liquidity in companies registered in the Jakarta Islamic Index (JII) for the period of 2015 -2018. Regression analysis is used to test hypotheses that link variations in TBL reporting rates with factors that might influence corporate and non-financial financial disclosures. Specifically, we found that, for total TBL disclosure researchers combined the categories of company size, profitability, leverage, share ownership and liquidity.

Based on the background above, the main problem in this research is how the disclosure of social responsibility such as Company Size, Profitability, Leverage, Type of Share Ownership, and Liquidity can influence the Triple bottom line disclosure in Islamic companies registered in the Jakarta Islamic Index (JII) period 2015-2018.

\section{Theoritical Review}

\subsection{Triple Battom Line}

Triple bottom line (TBL) is a framework or theory that recommends that companies commit to focus on social and environmental issues as well as on profits. TBL believes that instead of one bottom line, there should be three: profit, people, and the planet. TBL seeks to measure the level of corporate commitment to corporate social responsibility and its impact on the environment over time. The Elkington TBL framework advances the goal of sustainability in business practices, where companies see more than just profits by incorporating social and environmental issues to measure the full cost of doing business. In addition, the TBL principle states that if a company only focuses on finance and does not examine how it interacts socially, the company cannot see the whole picture, and thus cannot explain all the costs of doing business.

According to TBL theory, companies must work together in three domains:

a. Profit: The traditional measure of company profit - profit and loss account (P\&L).

b. People: Measure how socially responsible an organization is during its operations.

c. Planet: Measuring how responsible a company is to the environment.

By focusing on these three interrelated elements, triple bottom line reporting can be an important tool to support the company's sustainability goals. (www.investopedia.com) 
International Journal of Economics, Business and Accounting Research (IJEBAR)

Peer Reviewed - International Journal

Vol-4, Issue-1, 2020 (IJEBAR)

E-ISSN: 2614-1280 P-ISSN 2622-4771

https://jurnal.stie-aas.ac.id/index.php/IJEBAR

\subsection{Company size}

Previous literature has identified several reasons for the relationship between disclosure and company size. Lang and Lundholm (1993) note that the cost of preparing company disclosures decreases with firm size due to economies of scale. It was also argued that the cost of disseminating disclosure might be lower for large companies because news media are more likely to report news about larger companies and analysts are more likely to attend their meetings (Lang and Lundholm, 1993). Following this argument, we expect a positive relationship between company size and the number of TBL disclosures.

Alternative reasons for expecting a positive relationship between firm size and company disclosure are provided in agency theory (Jensen and Meckling, 1976). Larger companies tend to have higher agency costs because of the higher information asymmetry between managers and shareholders. To reduce the agency costs, large companies tend to disclose more information. To overcome government intervention, large companies have stronger incentives to improve their company reporting and/ or minimize reported income (Watts and Zimmerman, 1986). This opinion is in line with the opinion of Skinner (1994) which shows that larger companies may have greater incentives for full disclosure to minimize the possibility of litigation costs.

Finally, the transaction cost hypothesis from King et al. (1990) predicts that corporate disclosure tends to increase with firm size because profits by trading personal information are higher for larger companies, which in turn will increase incentives and demand for more information about large companies. Research by Singhvi, Desai (1971) and Wallace, Naser (1995) also showed that smaller companies were more likely than larger companies to feel that greater disclosure would damage their competitive position. This argument also leads to predictions in this paper that the number of TBL disclosures is positively related to company size.

\subsection{Company profitability}

The implications of the theory for the relationship between disclosure and corporate profitability vary. It is generally argued that company managers who are more profitable are more likely to disclose because of adverse signal and/ or selection incentives (Verrecchia, 1983). On the other hand, managers may have an incentive to provide information that is unfavorable with the aim of reducing the possibility of legal liability (Lang and Lundholm, 1993; Skinner, 1994). Empirical evidence about the relationship between earnings performance and disclosure also varies. Some previous studies (Singhvi and Desai, 1971; Penman, 1980; Lev 1990; Lang and Lundholm, 1993) say that companies that experience favorable earnings performance tend to disclose more frequently and comprehensively.

\subsection{Leverage}

According to Jensen and Meckling (1976) said that companies with higher leverage lead to higher monitoring costs. Management can disclose more frequently or comprehensively for the purpose of helping to ensure the debt holders of the company's ability to pay off obligations. As leverage increases, the wealth potential from debt holders to shareholders also increases (Myers, 1977). Because debt holders can set prices to safeguard themselves with debt restrictions, companies with higher leverage make it possible to increase the level of corporate disclosure to minimize agency costs. 
International Journal of Economics, Business and Accounting Research (IJEBAR)

Peer Reviewed - International Journal

Vol-4, Issue-1, 2020 (IJEBAR)

E-ISSN: 2614-1280 P-ISSN 2622-4771

https://jurnal.stie-aas.ac.id/index.php/IJEBAR

\subsection{Type of Share Ownershipl}

The thing that underlies the management for the wide disclosure of the company's annual report, one of which is the company's share ownership of more than one person, even involving the wider community. In addition, the composition of companies with large shareholders will be in the public spotlight and under pressure from shareholders, the government as an assistant to the management to disclose company information as best as possible (Sudarmaji Sularto, 2007: 56). According to Jensen Mecling (1976) in Fitriana and Pratiwi (2014: 2) provides an explanation of share ownership on the extent of disclosure of the company's annual report that agency costs will increase in line with the increasing value of shares outstanding and is closely related to the proportion of ownership of the company. This is caused by the more shareholders, the more interested parties and consequently, the more parties who need information about the company and will cause a reaction to the management to make a more comprehensive disclosure.

\subsection{Liquidity}

Studies by (Wallace, Naser, 1995), and (Owusu, Ansah, 1998), suggest that company liquidity is an important instrument of corporate disclosure. Specifically, they argue that investors, creditors, regulators, and other users of company reports have problems regarding the company's going concern status. Thus, according to signaling theory, very good companies may have stronger incentives to provide better details in the companies' impregnation of their ability to meet long and short term financial obligations.

\section{Hypothesis}

Based on the theoretical studies that have been explained before, then the hypothesis can be formulated as follows:

H1 : Firm Size Has Positive Impact on Disclosure of Triple Battom Line in Sharia Companies Registered in the Jakarta Islamic Index (JII) for the 2015-2018 Period.

H2 : Profitability has a Positive Impact on the Disclosure of Triple Battom Line in Sharia Companies Registered in the Jakarta Islamic Index (JII) for the 2015-2018 period.

H3 : Leverage Has a Positive Impact on Disclosure of Triple Battom Line in Sharia Companies Registered in the Jakarta Islamic Index (JII) for the 2015-2018 Period.

H4 : Share Ownership Has Positive Impact on the Disclosure of Triple Battom Line in Sharia Companies Registered in the Jakarta Islamic Index (JII) for the 2015-2018 period.

H5 : Liquidity has a Positive Impact on Disclosure of Triple Battom Line in Sharia Companies Registered in the Jakarta Islamic Index (JII) for the 2015-2018 period.

H6 : Company Size, Profitability, Leverage, Share Ownership, and Liquidity have Positive Impact on Triple Battom Line Disclosure on Sharia Companies Registered in the Jakarta Islamic Index (JII) for the 2015-2018 period.

\section{Research Method}

This research method is a quantitative method that aims to reveal data on field results. The population in this study are companies registered in the Jakarta Islamic Index (JII) in a row from the period 2015-2018. The sampling technique uses proposive sampling which aims to get a sample that matches the purpose of the study. Criteria for companies that are sampled in this 
International Journal of Economics, Business and Accounting Research (IJEBAR)

Peer Reviewed - International Journal

Vol-4, Issue-1, 2020 (IJEBAR)

E-ISSN: 2614-1280 P-ISSN 2622-4771

https://jurnal.stie-aas.ac.id/index.php/IJEBAR

study are companies listed in JII in a row from 2015-2018. Researchers take companies that go public and have enormous financial assets. The data collection was obtained from secondary data obtained from data www.idx.co.id that has been audited with an annual report issued by companies listed on the Jakarta Islamic Indexs (JII) with the period of 2015-2018.

The data analysis technique in this study uses Multiple Linear Regression analysis techniques with the help of SPSS Program Persi 16.0. Multiple linear regression analysis aims to examine the effect of independent variables and dependent variables. One of the requirements for multiple linear regression analysis is first, by conducting a $t$ test, which serves to determine the effect of the independent variable (X) partially affecting the dependent variable (Y). Second, the $\mathrm{F}$ Test, which aims to determine the effect of the independent variable (X) simultaneously influencing the dependent variable $(\mathrm{Y})$. Third, the Determination Coefficient Test (R Square or R Square), which aims to find out what percentage of influence exerted the independent variable $(\mathrm{X})$ on the dependent variable $(\mathrm{Y})$. The multiple linear regression equation is as follows: $\mathrm{Y}=\alpha+\beta 1 \mathrm{X} 1+\beta 2 \mathrm{X} 2+\beta 3 \mathrm{X} 3+\beta 4 \mathrm{X} 4+\beta 5 \mathrm{X} 5$

Where :

$\mathrm{Y}=$ Triple Battom Line at JII company

$\mathrm{A}=$ Constant

$\beta 1-\beta 4=$ Variable Regression Coefficient

$\mathrm{X} 1$ = Company Size

$\mathrm{X} 2=$ Profitability

$\mathrm{X} 3=$ Levarage

X4 = Type of Share Ownership

X5 = Liquidity

\section{Results And Discussion}

\subsection{Hypothesis Testing H1, H2, H3, H4, and $\mathrm{H} 5$ with the Statistical t Test}

The $\mathrm{t}$-test analysis was used to find out the partial effect of each independent variable (X) affecting the dependent variable (Y). The independent variable consists of company size, profitability, leverage, type of share ownership and liquidity. While the dependent variable is Triple Battom Line for companies listed on the 2015-2018 Jakarta Islamic Index (JII). The results of the statistical test can be seen in Table 1.1 below:

Table 1.1

Statistical t Test Results

Coefficients ${ }^{\mathrm{s}}$

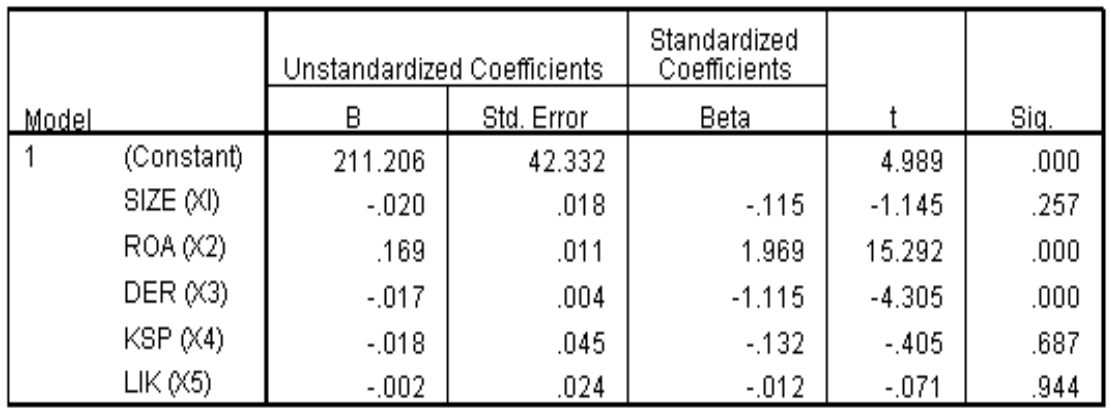

Source: Data processed 
International Journal of Economics, Business and Accounting Research (IJEBAR)

Peer Reviewed - International Journal

Vol-4, Issue-1, 2020 (IJEBAR)

E-ISSN: 2614-1280 P-ISSN 2622-4771

https://jurnal.stie-aas.ac.id/index.php/IJEBAR

a. First Hypothesis (H1) Effect of Company Size on the Disclosure of Triple Battom Line in Sharia Companies Registered in the Jakarta Islamic Index (JII) for the period 2015-2018.

Based on the results of the t-test statistic in table 1.1 above, it can be found that the company size variable is 0.0257 , which means sig t $0.0257<0.05$. It can be concluded that $(\mathrm{H} 1)$ is accepted, which means that partially there is an influence between the size of the company on the disclosure of Triple Battom Line on the companies listed on the 2015-2018 Jakarta Islamic Index (JII).

These results can be interpreted that, the larger the size of the company, the wider the disclosure of financial statements that must be reported by the management. Whereas the smaller the size of the company tends to reduce the voluntary disclosure presented. According to stakeholder theory, the larger the size of the company the greater the parties involved in the company's activities. The number of interested parties in the company's activities has led to wider disclosure as a form of management accountability to meet the needs of adequate information for all stakeholders. The results of this study are in line with research conducted by Andri Pratiwi (2012), Prayogi (2003), Bunardi (2009), and Supriyadi (2010) which states that company size influences the extent of voluntary disclosure of financial statements.

b. Hypothesis Two (H2) Effect of Profitabilits on the Disclosure of Triple Battom Line in Sharia Companies Registered in the Jakarta Islamic Index (JII) for the 2015-2018 period.

Based on the results of the analysis of the statistical $t$ test above it can be seen that the profitability variable is worth 0,000 which means sig t $0,000<0.05$. It can be concluded that $(\mathrm{H} 2)$ is accepted, which means that partially the profitability variable has an influence on the disclosure of Triple Battom Line on companies registered in the Jakarta Islamic Index (JII) for the 2015-2018 period.

These results can be interpreted, both companies that have high or low profitability, are not significant indicators that can affect management policies in order to disclose company related information such as extensive voluntary disclosure. Based on the theory, high profitability shows the high profits earned by the company, with high profitability will reveal more financial statements, this is done for several reasons, including to show the performance of the company to shareholders that their hopes to get a return on investment have been fulfilled.

c. Third Hypothesis (H3) Effect of Leverage Against Triple Battom Line Disclosure in Sharia Companies Registered in the Jakarta Islamic Index (JII) for the 20152018 period.

Based on the results of the t-test statistic in table 1.1 above, it can be seen that the leverage variable has a value of 0,000 , which means sig $\mathrm{t} 0,000<0.05$. It can be concluded that $(\mathrm{H} 3)$ is accepted, which means that partially there is the influence of variable leverage on the disclosure of Triple Battom Line on companies listed on the 2015-2018 Jakarta Islamic Index (JII).

These results can be concluded, both companies that have high or low leverage levels, are not significant indicators that influence management policies to widely disclose company information. The theory underlying this study explains that the higher 
International Journal of Economics, Business and Accounting Research (IJEBAR)

Peer Reviewed - International Journal

Vol-4, Issue-1, 2020 (IJEBAR)

E-ISSN: 2614-1280 P-ISSN 2622-4771

https://jurnal.stie-aas.ac.id/index.php/IJEBAR

the leverage of the company, the greater the agency cost for the company or in other words the greater the possibility of transfer of prosperity from long-term overstretched to shareholders and managers. So to reduce this, companies are required to make broader disclosures to meet long-term credit information needs.

d. The fourth hypothesis (H4) is the effect of share ownership on the disclosure of Triple Battom Line in Sharia Companies Registered in the Jakarta Islamic Index (JII) for the 2015-2018 period.

Based on the results of the t-test statistic in table 1.1 above, it can be seen that the company's size variable is 0.0687 , which means sig t $0.0687>0.05$. It can be concluded that the hypothesis $(\mathrm{H} 4)$ is rejected, which means that partially there is no influence between share ownership on the disclosure of Triple Battom Line in companies listed on the Jakarta Islamic Index (JII) for the 2015-2018 period.

These results can be interpreted that, companies that have a high or low portion of public share ownership, are not significant indicators that affect management policies to widely disclose company information. This research proved to be successful in supporting previous research conducted by dimas Hananto (2013), who found that there was no relationship between the types of share ownership owned by outside investors to the complete disclosure by the company.

e. The Fifth Hypothesis (H5) Effect of Liquidity on the Disclosure of Triple Battom Line in Sharia Companies Registered in the Jakarta Islamic Index (JII) for the 2015-2018 Period

Based on the results of the t-test statistic in table 1.1 above it can be seen that the variable liquidity is 0.0944 which means sig t $0.0944>0.05$. So it can be concluded that (H5) is rejected, which means that partially there is no effect between liquidity on Triple Battom Line disclosures in sharia companies registered in the Jakarta Islamic Index (JII) for the 2015-2018 period.

These results can be concluded that, the lower the liquidity possessed, the wider the voluntary disclosure will increase. Rather, if a high liquidity ratio will reduce the extent of voluntary disclosure. The theory underlying this research explains that the higher the liquidity of the company will increase the extent of voluntary disclosure, because with high liquidity, the company will be motivated to convey it to the users of information in hopes of increasing the value of the company's work. If the user of information knows a good company performance, the company will have a positive impact. But on the contrary, if liquidity is low, it is possible for companies to tend to hide information, because they have a concern that the value of the company is decreasing. The results of this study are in line with research conducted by Suta and Hery (2012), and Wicasono who said that liqudity had no effect on the extent of disclosure. These results explain if the risk of liquidity is low, the extent of voluntary disclosure will increase. Whereas if "high liquidity tends to reduce the extent of voluntary disclosure.

\subsection{Hypothesis Testing (H6) with Statistical F Test}

The analysis of the $\mathrm{F}$ statistic test aims to find out the simultaneous influence between independent variables namely company size, profitability, share ownership leverage and liquidity 
International Journal of Economics, Business and Accounting Research (IJEBAR)

Peer Reviewed - International Journal

Vol-4, Issue-1, 2020 (IJEBAR)

E-ISSN: 2614-1280 P-ISSN 2622-4771

https://jurnal.stie-aas.ac.id/index.php/IJEBAR

on the dependent variable ie companies listed on the Jakarta Islamic Index (JII) for the 20152018 period. As for the $\mathrm{F}$ statistical test results can be seen in table 1.2 below:

Table 1.2

F Statistic test results

ANOVA ${ }^{\text {b }}$

\begin{tabular}{|c|c|c|c|c|c|c|}
\hline Model & & $\begin{array}{l}\text { Sum of } \\
\text { Squares }\end{array}$ & $d f$ & Mean Square & $F$ & Sig. \\
\hline \multirow[t]{3}{*}{1} & Regression & 127653.571 & 5 & 25530.714 & 68.268 & $.000^{\circ}$ \\
\hline & Residual & 20194.797 & 54 & 373.978 & & \\
\hline & Total & 147848.368 & 59 & & & \\
\hline
\end{tabular}

a. Predictors: (Constant), LIK (X5), SIZE (X), ROA (X2), DER (X3), KSP $(X 4)$

Source: Data processed

Based on the results of the F statistical test above it can be seen that the significance value of $F$ is $0,000<0.05$. It can be concluded that (H6) is accepted which means that there is a simultaneous relationship between company size, profitability, leverage, share ownership and liquidity to the disclosure of Triple Battom Line in companies listed on the Jakarta Islamic Index (JII) for the 2015-2018 period.

\subsection{Determination Coefficient Test Results ( $R$ square)}

Determination Coefficient (R square) test aims to predict and find out how much contribution is given by independent variables namely company size, profitability, leverage, share ownership and liquidity, simulantly affect the dependent variable ie companies registered in the Jakarta Islamic Index (JII) period 2015-2018. The results of the coefficient of determination test can be seen in Table 1.3 below:

Table 1.3

\begin{tabular}{|c|c|c|c|c|}
\hline & \multicolumn{4}{|c|}{ Model Summary } \\
\hline Mode & $R$ & Roguare & $\begin{array}{c}\text { Adjusted R } \\
\text { Squale }\end{array}$ & $\begin{array}{l}\text { Std Error of } \\
\text { the Estimate }\end{array}$ \\
\hline 1 & $929^{\circ}$ & .863 & .851 & 193950 \\
\hline
\end{tabular}

Based on the analysis of the coefficient of determination test (R Square) it can be seen that the $\mathrm{R}$ square value of 0.863 or $86.3 \%$. These results indicate that the disclosure of Triple Bttom Line for companies registered in the Jakarta Islamic Index (JII) is influenced by the variable 
International Journal of Economics, Business and Accounting Research (IJEBAR)

Peer Reviewed - International Journal

Vol-4, Issue-1, 2020 (IJEBAR)

E-ISSN: 2614-1280 P-ISSN 2622-4771

https://jurnal.stie-aas.ac.id/index.php/IJEBAR

company size, profitability, leverage, share ownership and liquidity of $86.3 \%$ and the rest is influenced by other variables that researchers cannot explain

\section{Conclusions}

Based on the results of multiple linear regression analysis with the test, it can be concluded that partially company size, liquidity and leverage variables influence the disclosure of Triple Battom Line on companies registered in the Jakarta Islamic Index (JII) for the 2015-2018 period. While share ownership and liquidity variables do not affect the disclosure of Triple Battom Line in companies listed in the 2015-2018 Jakarta Islamic Index (JII). The F statistic test results can be concluded that simultaneously variable company size, profitability, leverage, share ownership, and liquidity affect the Triple Battom Line disclosure in companies listed on the Jakarta Islamic Index (JII) for the 2015-2018 period. For the test results the coefficient of determination (R square) has a value of 0.863 which shows that $86.3 \%$ is the contribution of the variable company size, profitability, leverage, share ownership and liquidity can affect the Triple Battom Line disclosure on companies listed on the Jakarta Islamic Index ( JII) period 2015-2018.

\section{Reference}

Sandra, Aulia dan Idris Kartawijaya, "Analisis Pengungkapan Triple Bottom Line dan Faktor yang Mempengaruhi: Lintas Negara Indonesia dan Jepang", Skripsi, Fakultas Ekonomi Universitas Syiah Kuala, Banda Aceh, 2011.

Fitriana, Noorlaila dan Prastiwi, Andri, "Faktor-Faktor yang Mempengaruhi Luas Pengungkapan Sukarela Dalam Annual Report", Journal of Accounting: Undip, Semarang, 2014.

Cooke T, An, "Assessment of Voluntary Disclosure in the Annual Reports of Japanese Corporations", The International Journal of Accounting, 1991, pp. 174-189.

Craven, B. and Marston, C., "Financial Reporting On the Internet by Leading UK Companies", The European Accounting Review, 1999, pp. 321-333

Dye R. and Sridhar S, "Industry Wide Disclosure Dynamics", Journal of Accounting Research 33, (1995), pp. 157-174

Elkington J, Cannibals with Forks, “The Triple Bottom Line Of 21 st Cetury Business”, Oxford: Capston, 1997.

Jensen M. and W. Meckling, "Theory of the Firm: Managerial Behavior, Agency Costs and Ownership Structure", Journal of Financial Economics, 1976, pp. 305-360.

Jensen M. and W. Meckling, "Theory of the Firm: Managerial Behavior, Agency Costs and Ownership Structure", Journal of Financial Economics, 1976, pp. 305-360.

King R. G. Pownall and G. Waymire, "Expectations Adjustments Via Timely Management Forecasts: Review, Synthesis, and Suggestions for Future Research", Journal of Accounting Literature, 1990, pp. 113-144

Lang M. and R. Lundholm, "'Cross-Sectional Determinants of Analyst Ratings of Corporate Disclosures", Journal of Accounting Research, 1993, pp. 246-271.

Lev B. and S. Penman, "Voluntary Forecast Disclosure, Nondisclosure, and Stock Prices", Journal of Accounting Research, 1990, pp. 49-76.

Myers S, "Determinants of Corporate Borrowing", Journal of Financial Economics, 1977, pp. $147-175$. 
International Journal of Economics, Business and Accounting Research (IJEBAR)

Peer Reviewed - International Journal

Vol-4, Issue-1, 2020 (IJEBAR)

E-ISSN: 2614-1280 P-ISSN 2622-4771

https://jurnal.stie-aas.ac.id/index.php/IJEBAR

Owusu, Ansah S "The Impact of Corporate Attributes on the Extent of Mandatory Disclosure and Reporting by Listed Companies in Zimbabwe", The International Journal of Accounting, 1998, pp. 605-631.

Oyelere, P.F. Laswad and R. Fisher, "Determinants of Internet Financial Reporting by New Zealand Companies", Journal of International Financial Management and Accounting, 2003, pp. 26-63.

Penman, S, "An Empirical Investigation of the Voluntary Disclosure of Corporate Earnings Forecasts", Journal of Accounting Research, 1980, pp. 132-160.

Singhvi. S. and H. Desai, "An Empirical Analysis of the Quality of Corporate Financial Disclosure", The Accounting Review, 1971, pp. 129-138.

Skinner. D, "Why Firms Voluntarily Disclose Bad News?", Journal of Accounting Research, 1994, pp. 38-60.

Sudarmaji, Ardi Murdoko dan Lana Sularto, Pengaruh Ukuran Perusahaan, Profitabilitas, Leverage, dan Jenis Kepemilikan Perusahaan Terhadap Luas Voluntary Disclosure Laporan Keuangan Tahunan, Proceeding PESAT Auditorium Kampus Gunadarma, 21-22 Agustus 2007.

Verrecchia, R, "Discretionary Disclosure", Journal of Accounting and Economics, 1983, pp. 179-194.

Wallace, R. and K. Naser, "Firm Specific Determinants of the Comprehensiveness of Mandatory Disclosure in the Corporate Annual Reports of Firms Listed on the Stock Exchange of Hong Kong”, Journal of Accounting and Public Policy, 1995, pp. 311-368.

Watts, R. and J. Zimmerman, Positive Accounting Theory (Englewood Cliff, NJ: Prentice- Hall Inc, 1986). 